\title{
Syntactic Analysis of Kimbeere Relative Clauses
}

\author{
Peter Kinyua Muriungi ${ }^{1}$, Nancy Mbandi Mutange ${ }^{2}$ \\ ${ }^{1}$ Tharaka University College, Gatunga, Kenya \\ ${ }^{2}$ Chuka University, Chuka, Kenya \\ Email: muriungip@gmail.com
}

How to cite this paper: Muriungi, P. K., \& Mutange, N. M. (2019). Syntactic Analysis of Kimbeere Relative Clauses. Open Journal of Modern Linguistics, 9, 561-579. https://doi.org/10.4236/ojml.2019.96041

Received: March 10, 2019

Accepted: December 20, 2019

Published: December 23, 2019

Copyright $\odot 2019$ by author(s) and Scientific Research Publishing Inc. This work is licensed under the Creative Commons Attribution International License (CC BY 4.0).

http://creativecommons.org/licenses/by/4.0/

\section{c) (i) Open Access}

\begin{abstract}
This paper provides a syntactic analysis of noun phrase movement in raising predicates in Kimuthambi. The study is guided by the Principles and Parameters theory by Chomsky \& Lasnik (1993) and in particular, the Minimalist Program developed by Chomsky (1995). This theory recognizes that there is always a trigger movement which is the need to check features at an appropriate landing site. The paper demonstrates that Raising in Kimuthambi is triggered by need to check case features. Since raising verbs cannot assign case to a NP, the NP must move to a position in a sentence where it can be assigned case. This according to Carnie (2007) is due to the fact that the NP and the case assigner must be local in such a way that it must be the specifier or the complement of the case assigner, in order to check the feature of case. Case therefore becomes a mandatory trigger for movement of NPs that are not in positions that can be assigned case as in the case of raising predicates. The paper also demonstrates that unlike in English where raising occurs out infinitive clauses only, there is hyper raising in Kimuthambi where raising can occur out of a finite clause.
\end{abstract}

\section{Keywords}

Raising, Hyper Raising, Finite Clause, Non-Finite Clause

\section{Introduction}

There are two competing analysis of relative clauses-the head raising analysis (Kayne, 1994) and the adjunction analysis. The paper demonstrates that the data facts from Kimbere support the head raising analysis.

\section{Adjunction Analysis versus Head Raising Analysis}

Kayne's Head Raising Analysis was used because of the advantages it has over Adjunction Analysis. According to Ngonyani (2001), in Adjunction Analysis, 
the relative clause (CP) appears adjoined to the right of the head NP. The head of the relative clause is base-generated in a position outside the relative and the wh-phrase moves from a position inside the relative clause. This analysis is based on the assumption that the relative clause is a modifier of the head. On the other hand, Kaynes's Head Raising Analysis analyzes the relative clause as the complement of the determiner $\left(\mathrm{D}^{\circ}\right)$. The head of the relative clause occupies the specifier of the $\mathrm{CP}$ position. The head of the relative clause is base generated outside the relative clause. The diagrams (1) \& (2) illustrate Adjunction analysis and Head Raising analysis respectively.

(1)



(Ngonyani, 2001)

(2)

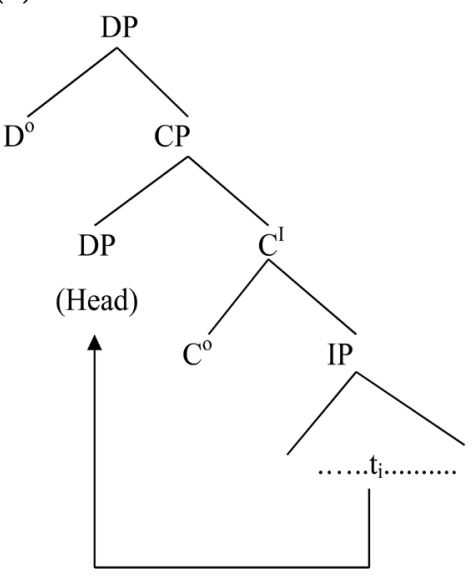

(Ngonyani, 2001)

Firstly, Head Raising Analysis is able to interprete pronouns bound by quantified noun phrases found lower in the relative clause. Sentence (3) illustrates this.

(3) ki-tabu ch-ake ${ }_{j}$ ch-a kwanza [amba-cho kila mw-

7-book 7-3S.POSS 7-CON first amba-7.REL every 1andishi $_{j}$ hu-ji vun- i- a t] hu- wwriter HAB-RFL be proud APP-FV HABbe-

a ki-zuri sana

FV 7-good very

"Her/his book for which every writer is very proud is very good"

(Ngonyani, 2001) 
In (3), the possessive pronoun "chake" (his/her) is bound by the quantified noun phrase "kila mwandishi" (every writer). "Every writer", which happens to be in the relative clause "ambacho kila mwandishi hujivunia" (which every writer is very proud) refers back to the possessive pronoun "chake" (his/her). The head noun "kitabu chake cha kwanza" (his/her first book) which is in the main clause is relativized as "ambacho" (which) in the relative clause. Worth mentioning is the co-indexing on "chake" and "mwandishi". Translated, "kitabu chake cha kwanza" (book his/her of first) would be "kitabu cha kwanza chakila mwandishi" (every writer's first book). This tells us that "kitabu chake cha kwanza" and "kila mwandishi" are constituents belonging together in this construction. In tree diagram (4) it is evident that before head raising, "kila mwandishi" c-commands "kitabu chake cha kwanza". Logically, it is expected that every writer has a first book which he/she is proud about. Therefore in (3) above, the constituents "kila mwandishi" and "kitabu chake cha kwanza" must be apart as a result of movement (head raising) of "kitabu chake cha kwanza". Consider tree diagram (4) derived from (3) for clarification.

(4)

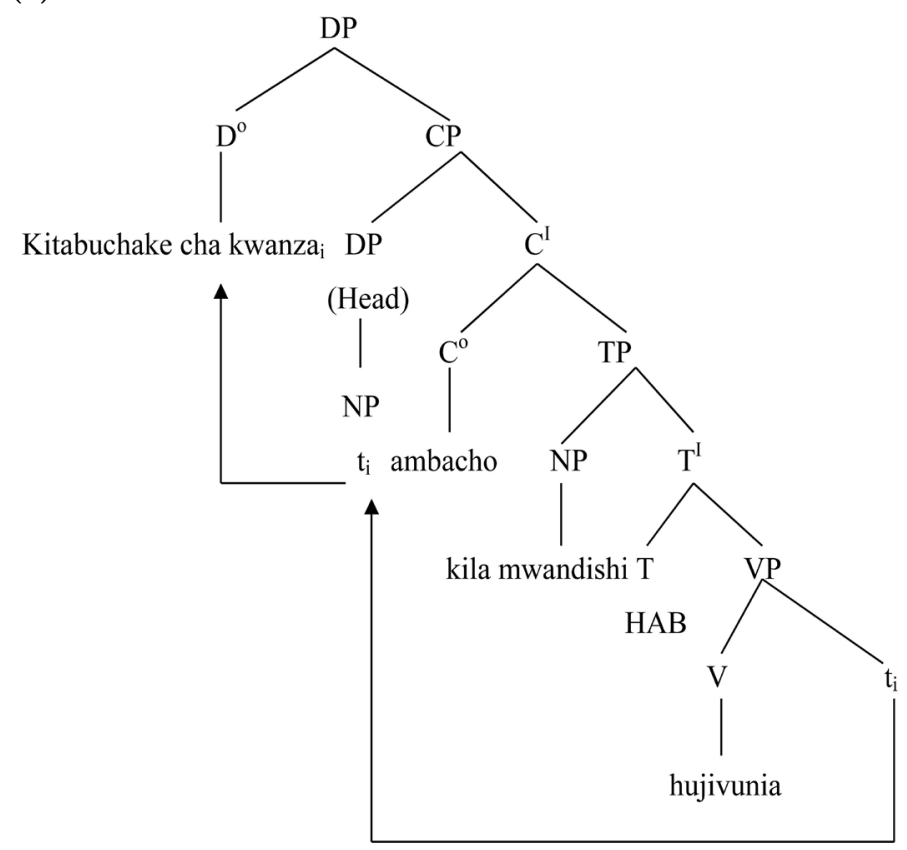

In diagram (4) it is clear that the head noun "kitabu chake cha kwanza" is raised from the position sister to the verb $(\mathrm{V})$ where it leaves a trace " $\mathrm{t}_{\mathrm{i}}$ ". The first time this head noun moves to the SpecCP and finally rests at $\mathrm{D}^{\circ}$. Adjunction Analysis is not able to show this movement hence it was not preferred for analysis of relative clauses in this study.

Secondly, The Head Raising Analysis and not an Adjunction Analysis is able to explain relativization of idiom chunks. The idiom "kunda mbakî" in (5) literary means "give you some snuff (ground tobacco)" but idiomatically means "to punish you severely usually by way of beating."

(5) Eterera nĩngũgũkundia mbakĩ. 


$$
\begin{aligned}
& \text { E- terer a nĩ ngũ g- ũ-kundi a mbakĩ } \\
& \text { 2sg wait FV FOC1sg FUT 2sg-give FV snuff } \\
& \text { "You wait, I will punish you severely" }
\end{aligned}
$$

Note that without the verbal part "kundia" (give) of the expression, the nominal "mbakî" (snuff) cannot maintain the idiomatic sense. That is why (5) cannot be rephrased as (6).

(6) $\quad{ }^{*}$ Mbakĩ nĩgũkũrũra.

${ }^{*}$ Mbakĩ nĩ $\tilde{\mathbf{1}}$ g- $\tilde{u}$ kũ rũr

9.Snuff FOC9.it FUT 2Sg you bitter FV

"The snuff will be bitter to you"

Evidently, the verb "kuunda" is in the relative clause while the head noun "mbakî" relativized as "irrĩa" (in 7) is outside the relative clause. There is a requirement that idioms be contiguous; words that form an idiom be next to each other. When those words are not found next to each other, it must be as a result of movement. This movement especially of head nouns is what Kayne calls head raising. From this kind of arrangement we can deduce that the nominal part must have been raised from the relative to the main clause so that the sentence could look like (7). Diagram (8) which is derived from (7) illustrates this argument. In (8), the nominal part "mbakî" is relativized as "irĩa" and raised from a

\begin{tabular}{|c|c|c|c|c|}
\hline $\begin{array}{l}\text { Nĩ ng- } \tilde{u} \\
\text { FOC } \\
\text { FUT } 2 \text { sg }\end{array}$ & $\begin{array}{l}\text { kundi } \\
\text { give }\end{array}$ & $\begin{array}{l}\mathrm{a} \\
\mathrm{FV}\end{array}$ & $\begin{array}{l}\text { mbakĩ } \tilde{I} \text {-rĩa } \\
\text { 9.snuff 9-REL }\end{array}$ & $\begin{array}{l}\tilde{u}-\quad \begin{array}{l}\text { ta- } \\
\text { om }\end{array} \text { - NEG-AUX }\end{array}$ \\
\hline kundua & rĩing & & & \\
\hline niff & gain & & & \\
\hline
\end{tabular}

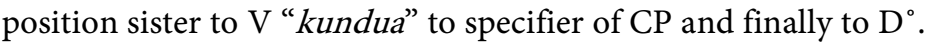

(7) Nĩngũkundia mbakĩ ĩrĩa ũtanakundua rĩ̃ngĩ.

I will give you a snuff which you have never been made to sniff again

"I will punish you worse than you have ever been punished"

(8)

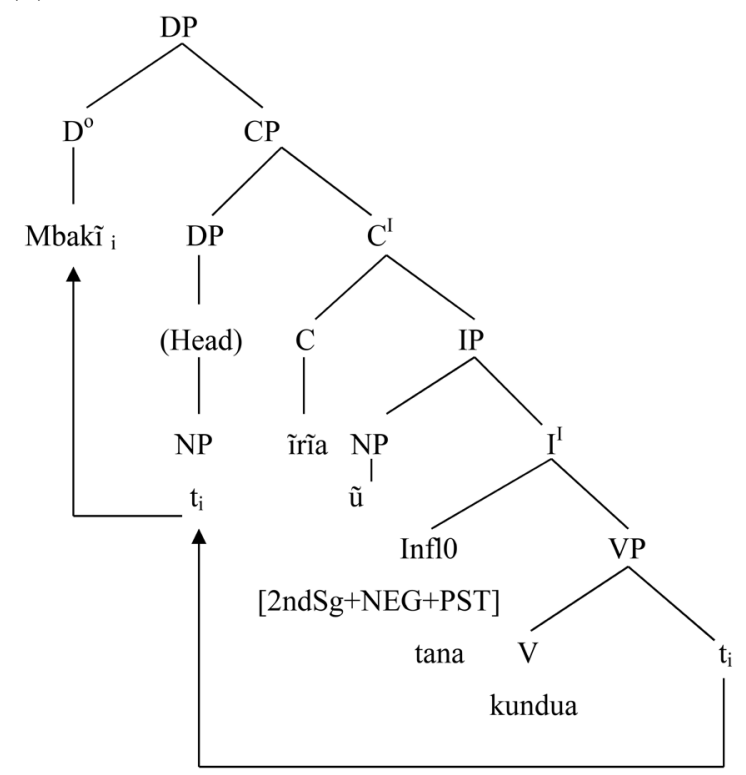


Thirdly, Head Raising Analysis is able to explain how raising can be made using idiomatic expressions with indefinite objects. In (9) the object "mbaû" (timber) is indefinite.

(9) Ngari nũrateithirie Njoki mbaũ

Ngari nĩ ũ- ra- te- ith- iri e

1.Ngari FOC2sg- PST-throw- CAUS- App FV

Njoki mbaũ.

1.Njoki 10.timber

(Ngari made Njoki throw timber)

"Ngari misled Njoki"

It would be ungrammatical to rephrase sentence (9) as (10). This is because "mbaũ irĩa" (timber which) carry a sense of definiteness that the idiom does not accommodate. Instead we should write it as (11).

(10) ${ }^{\star}$ Ngari nũrateithirie Njoki mbaũ irĩa.

${ }^{*}$ Ngari nĩ- $\tilde{u}-\quad$ r-a te- ith- iri- e

1.Ngari FOC 2sg PST throw CAUS App FV

Njoki mbaũ i-rĩa

1.Njoki 10.timber 10.REL

"Ngari made Njoki lose timber which"

(11) Mbaũ irĩa Ngari arateithirie Njoki itinatũkenia.

Mbaũ i-rĩa Ngari a- ra- te- ith- iri-

10.Timber 10-which 1.Ngari3sg PST throw-CAUS- App-

e Njoki i ti na tũ- ken- i- a

FV 1.Njoki 3pl NEG PST 1pl-please- PART-FV

"The misleading Ngari did to Njoki did not please us"

In (11) the idiom is "ta mbaû" literary meaning "throw timber" but idiomatically meaning "misleading". This means that the verbal part "ta" (throw) in "arateithirie" (he made to throw) must be closely connected to the nominal part "mbaû" (timber). For this nominal part, "mbaû" to be where it appears, it must have been raised from a place sister to the verbal part.

Fourthly, Head Raising Analysis provides a verysimple account of the typology of relative clauses. From the analysis, it is evident that Kimbeere has both internally headed and externally headed relative clauses. Internally headed ones like Free/Headless relative clauses do not involve head raising. According to Keenan (1985), other languages have a determiner marking a definiteness value on the internal that does not express the definiteness of the larger nominal phrase. In Bambara, there normally are no determiners, but there is a special determiner marking the internal head. Consider the Bambara structure in (12).
(12)

$$
\begin{array}{lllll}
\text { Tye ye ne } & \text { ye so } & \text { min ye } & \text { san } \\
\text { Man PST } 1 & \text { PST horse } & \text { REL see } & \text { buy }
\end{array}
$$
"The man bought the horse which I saw"

(Keenan, 1985)

Example (12) suggests that there is a special definiteness and value which 
Keenan calls REL, for the clause-internal element. Bambara is therefore a sufficient example of languages with internally headed relative clauses. On the other hand externally headed relative clauses like restrictive, appositives, direct, indirect, tenseless and "-ingĩ" involve head raising as evidenced in the tree diagrams appearing in this chapter.

In relation to X-bar theory (Cook, 1988), the maximal projection of a Kimbeere relative clause is a Determiner Phrase (DP). This DP branches into Determiner $\left(\mathrm{D}^{\circ}\right)$ and a Complementizer Phrase $(\mathrm{CP})$. Since $\mathrm{D}^{\circ}$ and $\mathrm{CP}$ are sisters, the $\mathrm{CP}$ in other words called the relative clause is a complement of $\mathrm{D}^{\circ}$.

Lastly, Head Raising Analysis is able to explain selectional relations between demonstratives and the relative clauses. Consider the Kiswahili expression (13) in which the relative clause "walichokiita uchokozi" (which they called provocation) is a complement of the demonstrative "kile" (that).



(Ngonyani, 2001)

Apparently, in (13a) there is agreement between the "ki-" in the demonstrative "kile" (that) and the "-ki-" attached to the relativizer "cho". Note that they are both in noun class 7 . This study therefore acknowledges the movement of " $k i$-" from the relative clause to the main clause as illustrated in (13b). This movement can only be as a result of raising which can only be explained by the Head Raising analysis and not by the Adjunction analysis.

\section{Syntactic Analysis of Different Types of Kimbeere Relative Clauses}

In this section I analyze different types of Kimbeere relative clauses using Kayne's Head Raising Analysis. These types include restrictive, appositive, direct, indirect, headless/free and tenseless relative clauses.

\subsection{Restrictive Relative Clause}

Zeller (2004) assumes that relative clauses, like all sentences, are CPs (Complementizer Phrases) according to Chomsky, 1986, 1995; Chomsky \& Lasnik, 1993; and Kayne, 1994. The CP corresponding to a restrictive relative clause is usually taken to be adjoined to the head noun (NP). Consider the English example (14) analyzed as (15).

(14) the dog which bit you

Zeller (2004) argues that the relative pronoun moves from the subject position, leaving a trace in SpecIP (Specifier of IP). However, a Kimbeere restrictive relative clause can be analysed as a complement of the determiner. Consider the Kimbeere example (16) which translates to (17). 
(15)



(16) Iratũ ĩrĩa Kagendo arabeere Njeri nĩ nene.

Iratũ i-rĩa Kagendo a- ra-be- er- $e$

8.Shoes 8-REL 1.Kagendo $\mathrm{sm}_{1}$-PST-give-PERF-FV

Njeri nĩ n-ene

1.Njeri FOC 8-big

"The shoes which Kagendo gave Njeri are big"

(17)

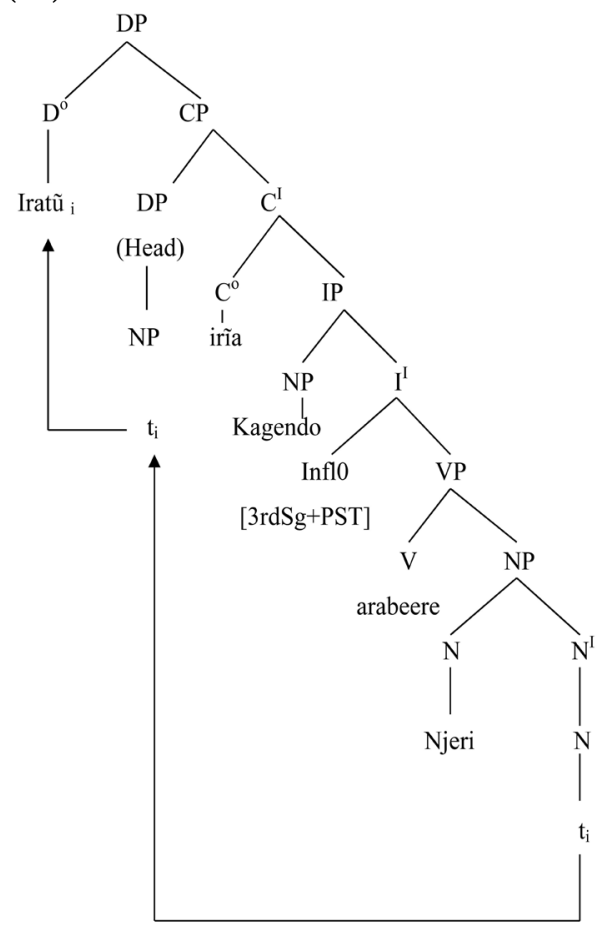

In tree diagram (17), the head noun "iratü" which happens to be a direct object is raised from a position sister to $\mathrm{N}$ (indirect object) "Njeri" to the specifier of $\mathrm{CP}$ and finally to $\mathrm{D}^{\circ}$.

\subsection{Appositive Relative Clause}

In an appositive relative clause, the head noun can be a common or a proper 
noun. Structure (18) would be analysed as (19). The (proper) head noun "Nya$g a^{\prime \prime}$ is raised from a position sister to $\mathrm{V}$, to the Spec $\mathrm{CP}$ and then to $\mathrm{D}^{\circ}$.

(18) Nyaga, ũrĩa tũraragĩrĩria, nĩwakinya.

\begin{tabular}{|c|c|c|c|c|}
\hline Nyaga, & $\tilde{u}-r \tilde{a} a$ & $t \tilde{u}$ & 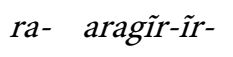 & $i-\quad a$, \\
\hline 1.Nyaga, & 1-REL & $1 \mathrm{pl}$ & PST talk Appl & PROG-FV, \\
\hline $\mathrm{w}$ & kiny- & $\mathrm{a}$ & & \\
\hline OC $\quad$ & arrive- & $\mathrm{FV}$ & & \\
\hline
\end{tabular}

"Nyaga, who we were talking about has arrived"

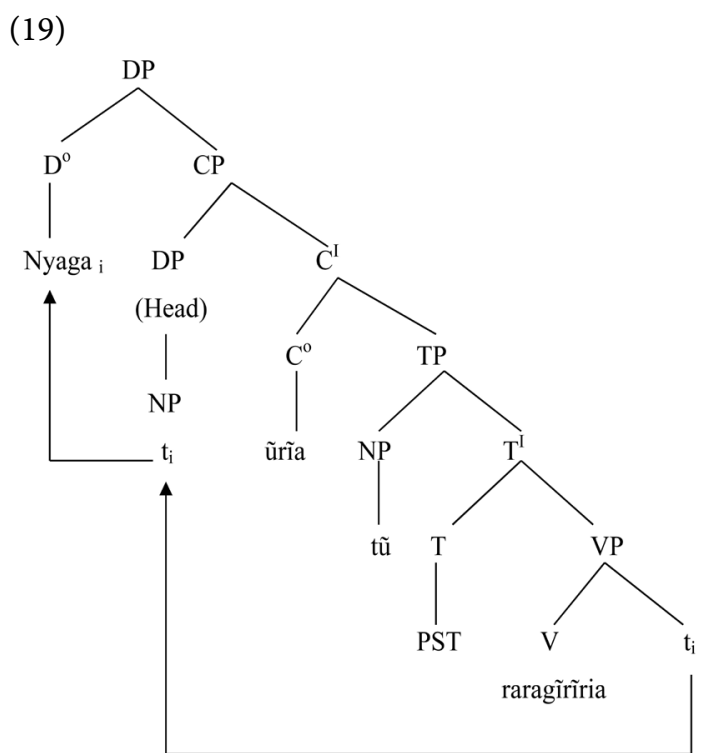

Demirdache (1991) makes a distinction between restrictive relatives and appositives. He says, a restrictive relative clause is right adjoined to the NP-projection, and hence it is c-commanded by the $\mathrm{D}^{\circ}$ head, whereas an appositive relative is adjoined to the whole $\mathrm{DP}$, so that it is higher than $\mathrm{D}^{\circ}$. According to (Bianchi, 2002), this hierarchical distinction nearly correlates with different interpretive rules: intersective modification between the restrictive relative and the NP "head" versus coreference between the relative pronoun and the DP "head" in appositives. Compare (20a) \& (20b).
(20) a) $\left[_{D P} D^{\circ}\left[_{N P}\right.\right.$
$[\mathrm{NP}][\mathrm{CP}]]]$
(Restrictive)
b) $\left[_{D P} \quad[D P\right.$
$\left.\left.\mathrm{D}^{\circ} \mathrm{NP}\right][\mathrm{CP}]\right]$
(Appositive)

(Bianchi, 2002)

The fact that coreference is involved in appositives explains why the "head" of an appositive relative is not necessarily a nominal category, but it can be any constituent that acts as an antecedent for a coreferential pronoun (Bianchi, 2002). The sentences in (21) illustrate this. In (21a) the appositive "which was unfortunate" modifies the clause "John arrived late" while in (21b), the appositive "which I will never be" modifies the adjective "courageous".

(21) a) [John arrived late], which was unfortunate.

b)Mary [courageous], which I will never be.

(Bianchi, 2002)

According to Bianchi (2002), Kayne extended the raising analysis to apposi- 
tive relatives. He proposed that the non-restrictive interpretation results from the LF movement of the IP sub constituent to the relative clause, to a position not c-commanded by the $\mathrm{D}^{\circ}$; this is the position he identified with SpecDP thus (22a) becomes (22b).

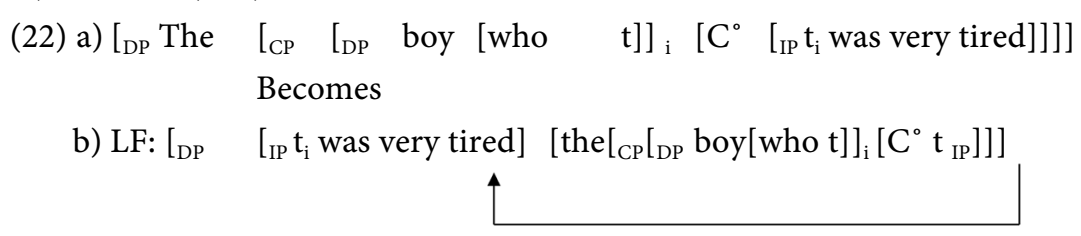

(Bianchi, 2002)

Bianchi's analysis is different from the one done on Kimbeere appositives in the current study in as far as the parts of speech modified by the relative clauses are concerned. While Kimbeere appositives seem to concentrate on description of nouns, Bianchi's analysis present appositives as describing adjectives and even entire main clauses as can be seen in (21b) \& (21a) respectively. However, the two agree in analyzing the appositive relative clause as a determiner phrase (DP) as evident in (19) and (22).

\subsection{Direct Relative Clause}

As earlier mentioned, the head noun of a direct relative clause corresponds to the subject. Evidently in (23), "Mwirintu" (lady) is the subject, "rĩire" ("eat" equivalent of "win") is the verb while "ngaar" (car) is the object. In (24), "mwiritu" is raised from the position SpecIP (specifier of IP), to Spec CP and then to determiner $\left(\mathrm{D}^{\circ}\right)$ position.

(23) Mwĩrĩtu ũrĩa ũrarĩ̃re ngaari arĩ gũkũ.

$$
\begin{aligned}
& \text { Mwĩrĩtu } \tilde{u}-r \tilde{I} a \quad \tilde{u}-{ }^{-} \text {ra- } r \tilde{1}-\tilde{I}^{-}{ }^{-} \quad e \quad \text { ngaari a- } \\
& \text { 1.Lady 1-REL 3sg- PST eat-Appl FV 9.vehicle } \mathrm{sm}_{3} \\
& \text { rĩ gũkũ } \\
& \text { be here } \\
& \text { "The lady who won a vehicle is here" }
\end{aligned}
$$

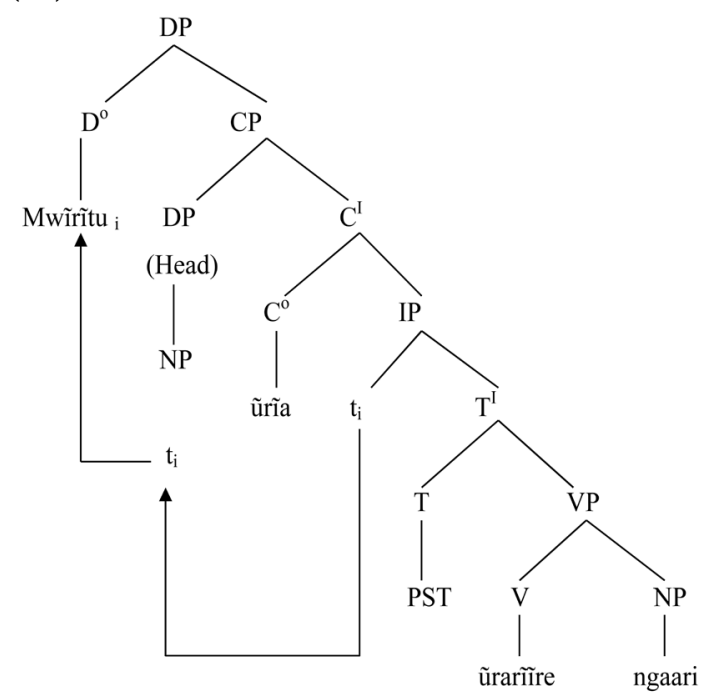


Zeller (2004) analyzes an English direct relative clause as an NP. In figure (26) derived from (25), it is evident that the relative pronoun moves from the subject position leaving a trace in SpecIP. Apparently the relative complementizer "that" is located in Comp ${ }^{\circ}$.

(25) a) The dog [which bit you]

b) The dog [that bit you]

(26)

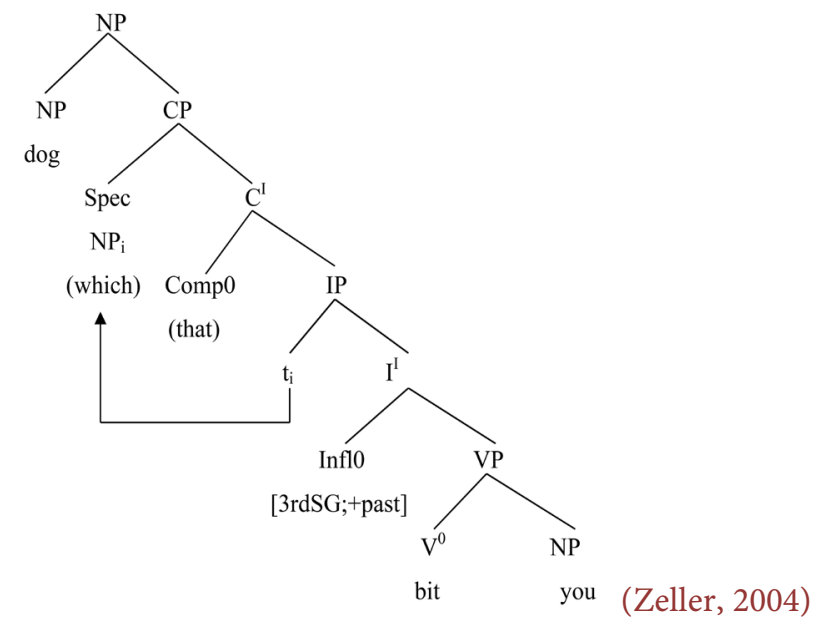

\subsection{Indirect Relative Clause}

The head noun in an indirect relative clause is a constituent other than one that corresponds with the subject of the verb in a sentence construction. According to Ngonyani (2001), subject-verb inversion is obligatory for object relativization. Consider (27a) in which there is inversion of the object "vitabu" (books) and the verb "nunua" (buy). In addition to subject-verb inversion, adds Ngonyani, Kiswahili has an alternate form using an independent form amba-REL. Compare the Kimbeere example in (28) with the Kiswahili ones in (27a) and (27b).

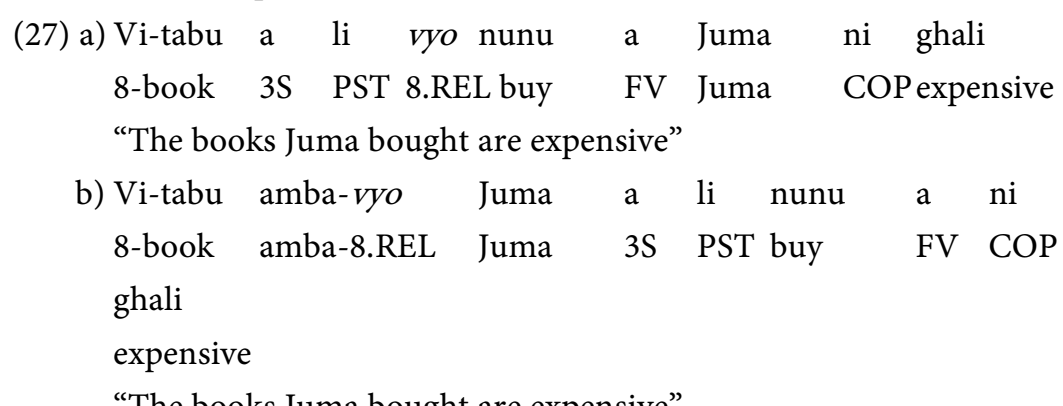

(Ngonyani, 2001)

Sentence (27b) can be described as what Mohammed (2001) referred to as "Amba"-relative clauses. He says that "Amba"-relative clauses are those that have "amba" as the root for the pronoun or adjectival. "Amba" is attached to a noun phrase marker consistent with the number and the class of the noun referred back to or described. For example in (27b) above, "amba" is attached to "-vyo" (noun phrase marker for "vitabu"). "-Vyo" and "vitabu" agree in class 
and number.

(28) Cũcũ ũrĩa twacerere ararĩ cibitarĩ.

Cũcũ ũ-rĩa tũ-a- cer- er- e a- ra-

1.Grandmother 1-REL 1pl-PST-visit- ApplFV om ${ }_{3}$ PST

rĩ cibitarĩ

AUX hospital

"The grandmother who we visited was in hospital"

From (28) we gather that "Cũcü" is a direct object. For this object to be in the position it occupies, it must have been raised from the position sister to Vto Spec $\mathrm{CP}$ and finally to $\mathrm{D}^{\circ}$ as can be seen in (29).

(29)

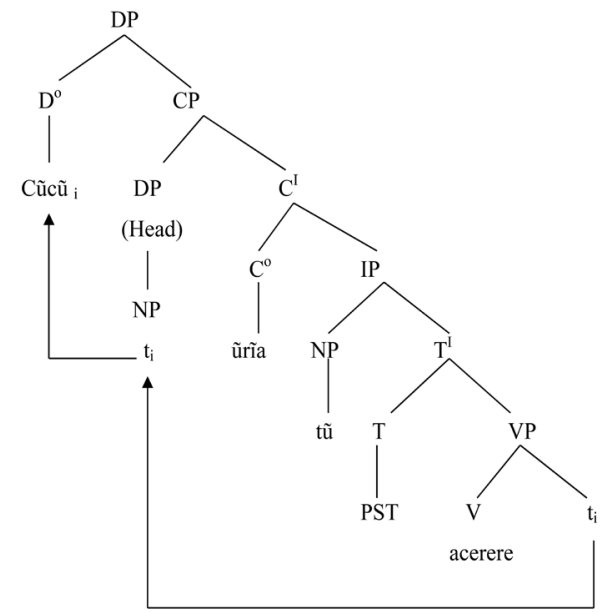

For Zeller (2004), in an indirect relative clause, the relative pronoun would be moved from a different position (not SpecIP as in direct relatives), as in (31), where the trace is in object position (sister to $\mathrm{V}^{\circ}$ ). Look at (30) from which (31) is drawn.

(30) a) The dog [which you bit]

b) The dog [that you bit]

(31)

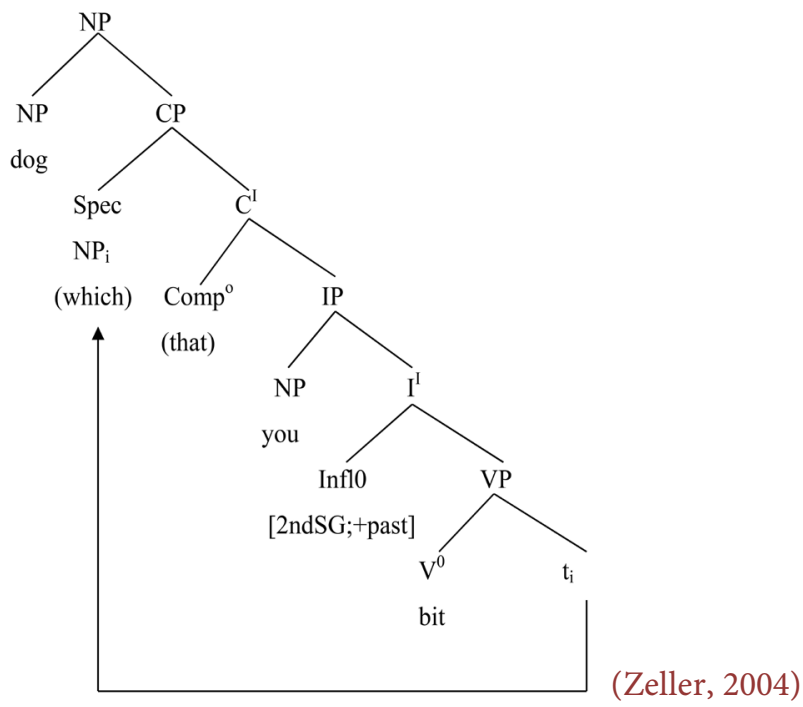


The head noun in an indirect relative clause can also take the form of an indirect object. Take alook at structure (32). From the tree diagram (33) it is noticeable that the indirect object "ciana" (children) is raised from a point between the agglutinative verb phrase "aragũrĩrĩtte" (had bought) and the direct object "geki" (cake).

(32) Ciana irĩa Joy aragũrĩrĩĩte geki nĩngenu.

\begin{tabular}{|c|c|c|c|}
\hline Ciana & i-rĩa Joy a-ra-gũr- & $\tilde{I} r-\quad \tilde{1} \tilde{t} t$ & $e$ \\
\hline 7.Children & 7-REL 1.Joysm ${ }_{1-}$ PST-buy- & Appl-PERF- & $\mathrm{FV}$ \\
\hline
\end{tabular}

"The children for whom Joy had bought a cake are happy"

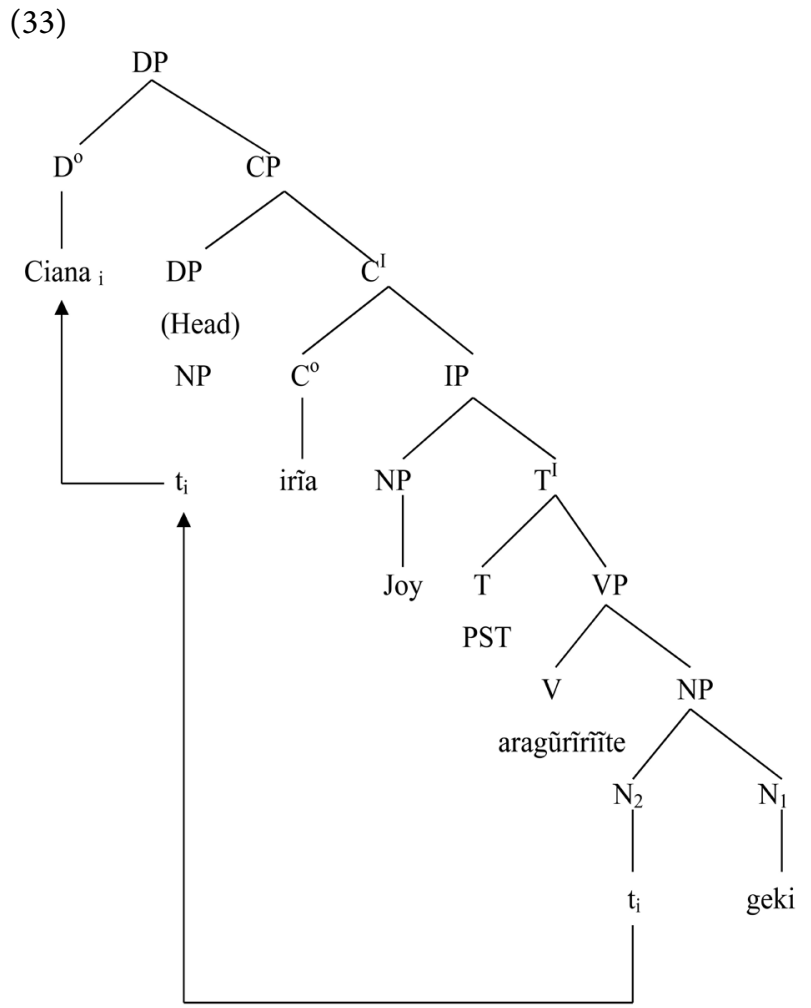

Arosio, Adani, \& Guasti (2007) showed that Italian children's comprehension of object relative clauses is modulated by different disambiguating cues. In (34a) we have an example of a subject relative in Italian, while in (34b) and (34c), we have object relatives disambiguated respectively by the position of the embedded subject or by number agreement on the embedded verb.

(34) a) Fammivederel' uomo cha salute le signore

"Show me the man that is greeting the ladies"

(b) Fammivederel' uomoche la signore salute

"Show me the man that the lady is greeting"

(c) Fammivederel' uomochesalutano le signore

"Show me the man that are greeting the ladies"

Show me the man that the ladies are greeting

For the sentence in (34a) the whole representation would be as (35) and the 
postverbal NP "le signore" would be assigned the grammatical function object. Note that in (35), Arosio, Adani and Guasti analyse the relative clause as a noun phrase (NP) and not as a determiner phrase (DP). Compare (35) with (33) above.

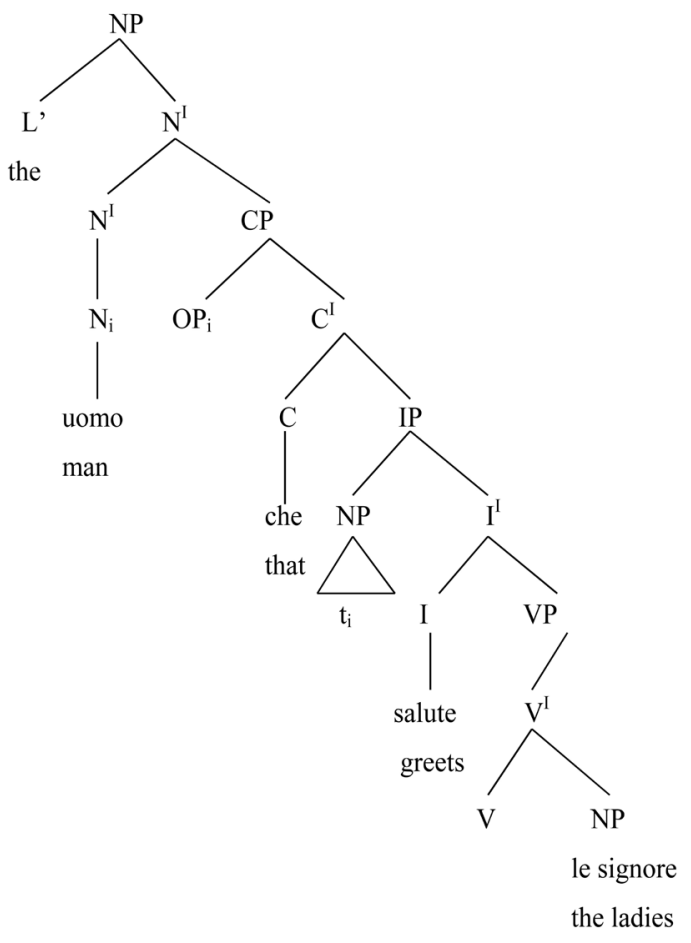

(Arosio, Adani, \& Guasti, 2007)

The analysis for the Italian relative clause in (35) is different from those of Kimbeere in that it is only the noun that moves as the determiner "the" is sister to $\mathrm{N}^{\mathrm{I}}$. In Kimbeere structures, the determiner and noun are together and so they are raised together from IP to SpecCp and finally to $\mathrm{D}^{\circ}$. The Italian analysis again assumes that a relative clause is an NP while this study takes a Kimbeere relative clause as a DP. For these reasons, this study could not adopt Arosio, Adani \& Guasti's analysis.

In a Kimbeere relative clause where the head noun is an adjunct, the head noun is raised from a position sister to verb. In (37) for instance, the head noun "kirroko" (in the morning) is raised from a point after the verb "yaurire" (it rained). It then moves to specifier of $\mathrm{CP}$ and finally to $\mathrm{D}^{\circ}$ positions. Look at sentence (36) from which syntactic tree (37) is derived.

(36) [Kĩroko kĩrĩa mbura yaurire] nĩkĩo nabandire.

\begin{tabular}{|c|c|c|c|}
\hline Kĩroko & kĩ-rĩa & mbura & ya-ur- ir- e nĩ kĩo \\
\hline 7.in the morning & 7-REL & 9.rain & $\mathrm{sm}_{9}$-rain-Compl-FVFOC 7.which \\
\hline n- a- band- & ir- & $\mathrm{e}$ & \\
\hline I- $\quad$ PST-plant- & PERF- & $\mathrm{FV}$ & \\
\hline "In the morning $\mathrm{n}$ & ch rain & rain is & en I planted" \\
\hline I planted in the $n$ & ing it & & \\
\hline
\end{tabular}




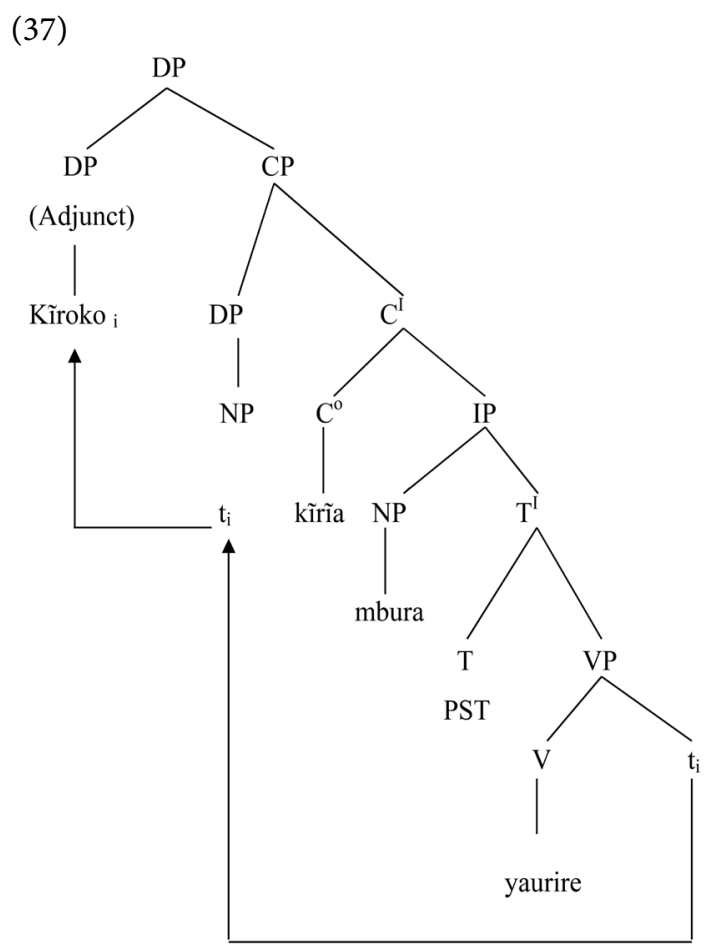

\subsection{Headless/Free Relative Clause}

According to Vries (2013), free/headless relative clauses display a relative pronoun but no overt noun. They usually behave as arguments (setting adverbial relativization aside) and hence are nominalized. Vries argues that much research is concerned with the position of the relative pronoun and the status of the empty head. On one hand, Bresan \& Grimshaw (1978) analyze the relative pronoun as occupying the position reserved for the head noun in the headed relatives. On the other hand, Groos \& Van Riemsdijk (1981) argue that the relative pronoun occupies the same position in the complementizer domain as in regular headed relative clauses.

For headless relative clauses, there is no head raising. This is because the relative marker does not refer back to a noun within the sentence. In (38) for instance, "îrĩa" (what) does not refer to any visible noun. Structure (38) can be presented syntactically as in (39).

(38) Ĩrĩa ya kũũra ndĩrĩ mũgarũri.

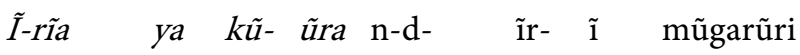

8-REL Prep get lost $\mathrm{sm}_{8}$-NEG-Appl-FV 1.savior

"That which is destined to get lost has no savior"

According to Lipps (2011), a headless relative clause can be analysed as a noun phrase that consists of a relative clause VP with a special predicate contribution. In this case relativization happens within an internal verb phrase rather than within a CP. In other words according to this analysis, there is no $\mathrm{CP}$ at all in headless constructions. Consider the Kiswahili example in (40) for comparison with (38). Sentence (40) is analyzed by Lipps as (41). 
(39)

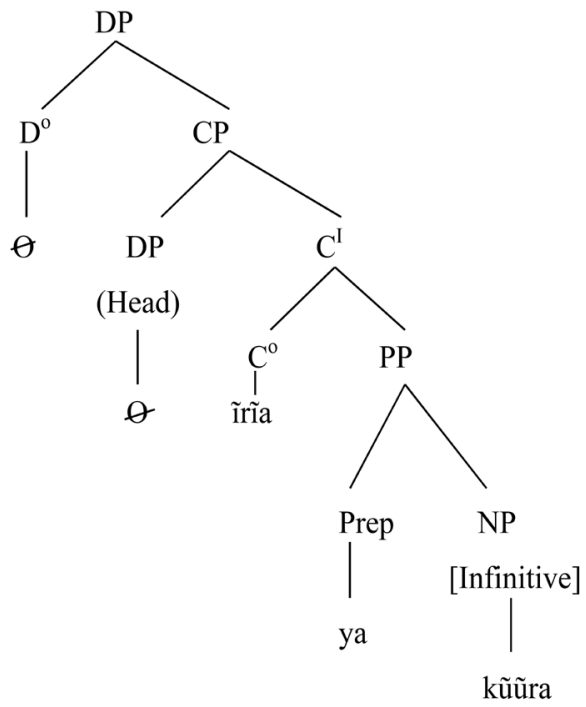

(40) liandikwalo

$\begin{array}{lllll}\mathrm{Li} & \text { andik } & \text { w } & \text { a } & \text { lo } \\ 5 & \text { write } & \text { PASS } & \text { FV } & \text { 5.REL }\end{array}$

"that which is written"

(Ashton, 1987)

(41)

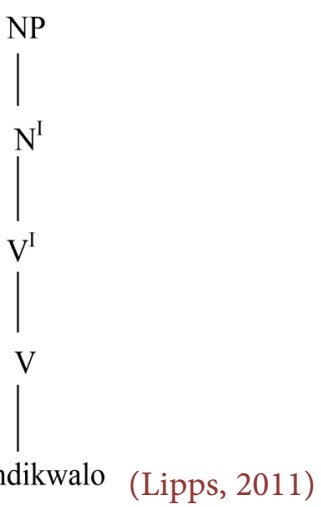

This study adopted Kayne's Head Raising Analysis rather than Lipps' analysis because the two differ in the labelling of a headless relative clause and relative clauses in general. While Lipps calls a relative clause a noun phrase, Kayne considers it a complementizer phrase (CP). Secondly, in Lipps' analysis, relativization happens within an internal verb phrase while in Kayne's analysis it happens within a CP. This Study finds Kayne's analysis more elaborate than Lipps'. This is because while Kayne's analysis is able to show head noun movement in other types of relative clauses, Lipps' analysis does not give this evident of movement. For Lipps, it is as if the relative clause in (41) is internally headed and so does not require head raising. This is against what Kayne (1994) and Bianchi (1999) note about the typology of relative clauses: that externally headed relative clauses, such as those found in English and Kiswahili involve head raising. From this argument therefore, Lipps analysis is not accurate to analyze Kimbeere relative clauses since Kiswahili and Kimbeere have a lot in common. 
Just like headless relative clauses, free relative clauses do not involve head raising. This is because the supposed head noun fuses into the relative pronoun. In (42), the head noun is within the relative pronoun "kĩrĩa" (which). Syntactically, (42) would be represented as in (43).

(42) Kĩrĩa nonire nwa niĩ mbĩcĩ.

\begin{tabular}{|c|c|c|c|c|}
\hline$K \tilde{I}-r \tilde{a} a$ & $n-$ & $a-$ & on- & ir- $\quad e$ nĩ- $\quad$ wa niĩ \\
\hline 7-REL & 1 sg- & PST & see & PERF-FV FOC- only $1 \mathrm{sg}$ \\
\hline $\mathrm{mb}-$ & ĩc- & $\tilde{1}$ & & \\
\hline $\mathrm{n}_{1}-$ & know & $\mathrm{V}$ & & \\
\hline
\end{tabular}

"Only I know what I saw"

(43)



\subsection{Tenseless Relative Clause}

Tenseless relative clauses involve head raising. Consider diagram (45) which results from structure (44). Note that the part in brackets contains the head, "matumbï", and the relative clause "ma gũkunĩkirithia". This part is tenseless. Looking at (45), it is noticeable that the head noun "matumbî' (eggs) is raised from a position sister to verb to SpecCP position then to determiner $\left(D^{\circ}\right)$. Note that the structures (44) and (45) do not have tense markers and therefore are tenseless.

(44) Nĩngũretere [matumbĩ ma gũkunĩkĩrithia].

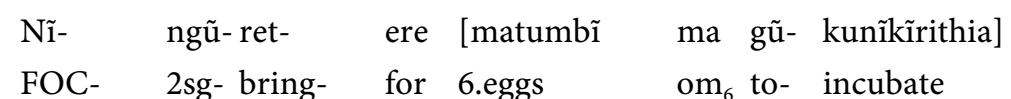

"I brought for you eggs to incubate"

\section{7. “-Ĩngĩ” Relative Clause}

Like restrictive, appositive, direct, indirect and tenseless relative clauses, there is head raising in "-ingli " relative clauses. The relative clause in (46) is analyzed as (47). In (47) for instance, the head noun "rori" (lorry) is raised from the position after the verb "onire" (saw) to DP and finally to $\mathrm{D}^{\circ}$. 
$(45)$

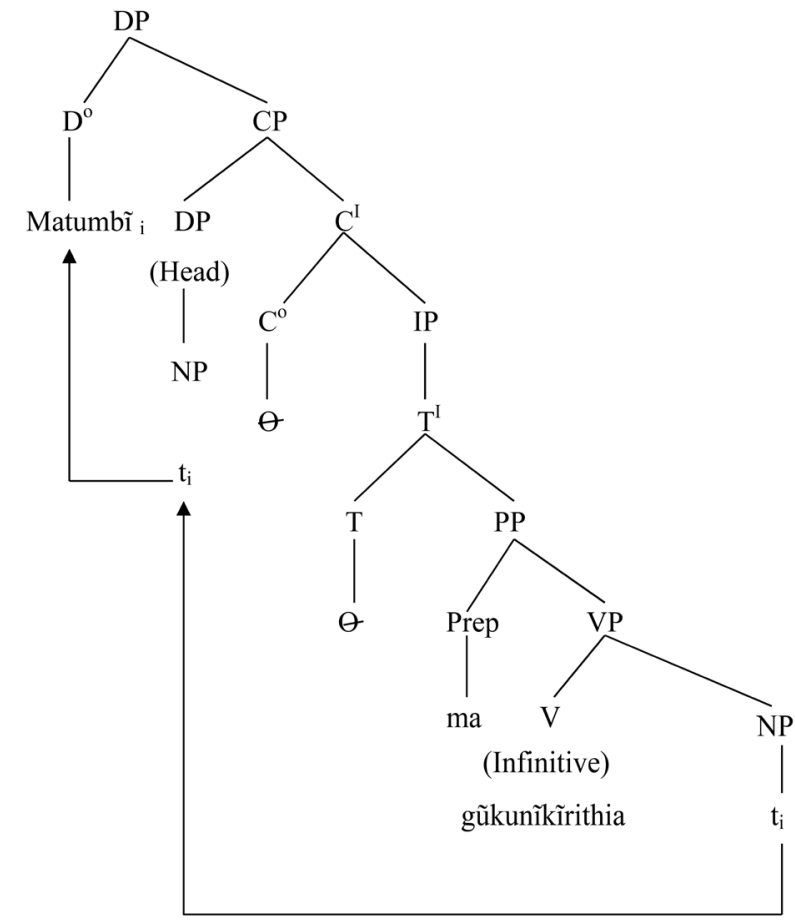

(46) Rori ĩnngĩ twonire ĩrakuĩite mbaũ.

Rori ĩ-ĩngĩ tũ- on-ir-e ĩ- ra- ku-

9.Lorry 9-REL 1pl- see-PERF-FV sm $_{9}$ - PST-carry-

ĩit- e mbaũ.

PERF- FV10.timber

"Another lorry we saw was carrying timber"

(47)

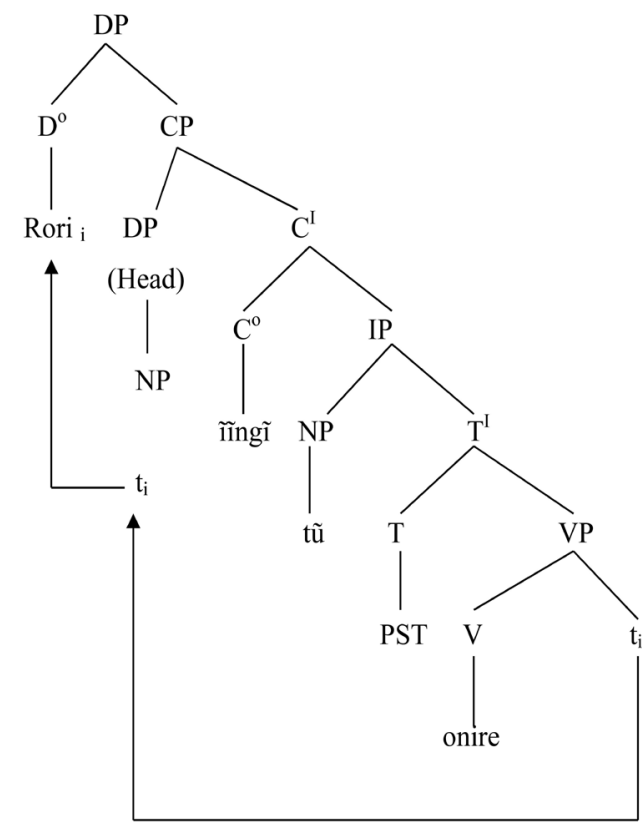

Table 1 summarizes syntactic analysis of Kimbeere relative clauses. It indicates which type involves and which one does not involve head raising. 
Table 1. Summary of head raising and no head raising in relative clauses.

\begin{tabular}{ccc}
\hline Type & Head Raising & No Head Raising \\
\hline Restrictive & $\checkmark$ & \\
Appositive & $\checkmark$ & \\
Direct & $\checkmark$ & \\
Indirect & $\checkmark$ & \\
Headless/Free & & \\
Tenseless & $\checkmark$ & \\
-Ĩngi & $\checkmark$ & \\
\hline
\end{tabular}

The ticked and unticked boxes indicate presence or absence of head raising respectively. From Table 1 it is evident that Kimbeere restrictive, appositive, direct, indirect, tenseless and "-ĩngï" relative clauses involve head raising. Headless/free relative clauses on the other hand do not involve head raising.

\section{Conclusion}

In summary, this paper gives advantages that Head Raising Analysis has over Adjunction Analysis. Tree diagrams for each type of Kimbeere relative clauses have been drawn using Head Raising Analysis. Contrasts are drawn between Kimbeere analysis and other analyses in other languages especially non Bantu languages. A summary of Kimbeere relative clauses involving head raising and those not involving head raising has also been made.

\section{Conflicts of Interest}

The authors declare no conflicts of interest regarding the publication of this paper.

\section{References}

Arosio, F., Adani, F., \& Guasti, M. T. (2007). Processing Grammatical Features by Italian Children. In Proceedings of GALA 2005. Newcastle upon Tyne: Cambridge Scholars Press.

Ashton, E. (1987). Swahili Grammar (Including Intonation). London: Longman.

Bianchi, V. (1999). Consequences of Antisymmetry: Headed Relative Clauses. Berlin: Mouton de Gruyter. https://doi.org/10.1515/9783110803372

Bianchi, V. (2002). Headed Relative Clauses in Generative Syntax-Part II. Glot International, 6, 1-13.

Bresan, J., \& Grimshaw, J. (1978). The Syntax of Free Relatives in English. Linguistic Inquiry, 9, 331-391.

Chomsky, N. (1986). Knowledge of Language. New York: Praeger Publishers.

Chomsky, N. (1995). Bare Phrase Structure. In G. Webelhuth (Ed.), Government and Binding Theory and the Minimalist Program. Cambridge: Blackwell.

Chomsky, N., \& Lasnik, H. (1993). Principles and Parameters Theory in Syntax: An International Handbook of Contemporary Research. Berlin: de Gruyter. 
Cook, V. (1988). Chomsky’s Universal Grammar: An Introduction to Grammar. Oxford: Basil Blackwell Ltd.

Demirdache, H. (1991). Resumptive Chains in Restrictives, Appositives, and Dislocation Structures. Cambridge, MA: MIT.

Groos, A., \& Van Riemsdjik, H. C. (1981). Matching Effects in Free Relatives: A Parameter of Core Grammar. In A. Belletti, L. Brandi, \& L. Rizzi (Eds.), Theory of Markedness in Generative Grammar: Proceedings of the 1979 GLOW Conference (pp. 171-216). Pisa, Italy: Scuola Normale Superiore.

Kayne, R. (1994). The Antisymmetry of Syntax. Cambridge, MA: MIT Press.

Keenan, E. (1985). Relative Clauses. In T. Shopen (Ed.), Language Typology and Syntactic Description (Vol. 2, pp. 141-170). Cambridge: Cambridge University Press.

Lipps, J. (2011). A Lexical-Functional Analysis of Swahili Relative Clauses. Oxford: Oxford University.

Mohammed, M. (2001). Modern Swahili Grammar. Nairobi: East African Educational Publishers Ltd.

Vries, M. D. (2013). Oxford Bibliographies in Linguistics: "Relative Clauses". Oxford: Oxford University Press. https://doi.org/10.1093/obo/9780199772810-0120

Zeller, J. (2004). Relative Clause Formation in the Bantu Languages of South Africa. Southern African Linguistics and Applied Language Studies, 22, 76-93.

https://doi.org/10.2989/16073610409486361 